No. 6(63), 2019, pp. 227-232

https://doi.org/10.12797/Politeja.16.2019.63.15

\author{
Kevin MENAGIE (D) \\ University of Amsterdam \\ kevin.menagie@student.uva.nl
}

\title{
THE REVIVAL OF DUTCH \\ NATIONALIST NARRATIVES \\ AS A THREAT TO EUROPEAN IDENTITY
}

ABSTRACT This article analyses the impact of a recent revival of nationalist narratives in The Netherlands on the issue of European identity. In the past decade, a sensitive and very salient debate has risen around the controversial figure of Zwarte Piet, part of a popular national festival called Sinterklaas. The article explains the nature of this tradition and elaborates on the development of the public debate on the topic. By analysing the defensive reaction towards criticism from Dutch action groups, the European Parliament and the United Nations, the article intends to expose an emphasis on nationalist arguments and invented traditions. It is often argued that the debate has already led to an increase in polarization in the country itself, but the article shows that it could also potentially function as a threat to European identity.

Key words: The Netherlands, nationalism, Zwarte Piet, Sinterklaas, European identity, United Nations, European Union 


\section{INTRODUCTION}

For centuries The Netherlands has been known as a progressive and tolerant country, both by its own inhabitants and the outside world. However, in recent years the country has been dealing with a heated discussion regarding controversial elements of the country's main holiday - Sinterklaas. The main issue is the presence of racial stereotypes in the way Sinterklaas' assistants are depicted. The name of these assistants is Zwarte Piet (plural: Zwarte Pieten) and critics believe that their image is based on a racist caricature that was invented during a period of slavery and colonialism. ${ }^{1}$ While the official explanation for his black color is that Zwarte Piet climbs down the chimney to leave presents for children ${ }^{2}$, many people see this as an excuse to play down racial elements. They often point out that his black color, golden earrings, colorful clothing, thick accent and inferior role are unacceptable aspects of a modern festival. ${ }^{3}$

While part of the population is in favor of adjustments to the image of Zwarte Piet, others believe this specific image is part of a tradition and should not be changed. Previously, however, the figure's image changed considerably without causing much controversy. The concept that Zwarte Piet's image is part of an old tradition is in line with the argument made by Hobsbawm and Ranger (1983), who believe that traditions which appear or claim to be old are often quite recent in origin and sometimes invented. ${ }^{4}$ This article will discuss the adjustments to the image of Zwarte Piet that have already been made, and the reasons why the current debate is much more sensitive than previously.

To paint a more concrete image, this article also analyses the development of protests against racist stereotypes and the way in which this has influenced the public debate in The Netherlands. Emphasizing the importance of national traditions, I will demonstrate that even a society that is often praised for its tolerance can fall back on racism and violence once minorities criticize its heritage. Attention will be paid to the way politicians have been dealing with criticism of Zwarte Piet and the way in which members of action groups have been treated in recent years. Overall, the article will demonstrate the way in which nationalist narratives can form a challenge for European identity.

\section{THE ROOTS: ZWARTE PIET AS A CULTURAL FIGURE}

In mid-November Sinterklaas arrives in the Netherlands by steamboat, accompanied by his helpers. According to the myth, Sinterklaas and his horse land on the roofs of houses on the $5^{\text {th }}$ of December, while the Zwarte Pieten distribute presents for children

\footnotetext{
K. Lemmens, “The Dark Side of 'Zwarte Piet': A Misunderstood Tradition or Racism in Disguise? A Legal Analysis”, The International Journal of Human Rights, vol. 21, no. 2 (2007), abstract.

2 Ibid., p. 124.

3 Ibid., p. 121.

4 E. Hobsbawm, T. Ranger, The Invention of Tradition, Cambridge 1983, p. 1.
} 
through the chimney. During November and December, Sinterklaas and a Zwarte Piet regularly appear in public spaces: there are many parades and they show up in public places that are often visited by children. ${ }^{5}$

For centuries, the celebrations around Sinterklaas were very different from the current version. From the late Middle Ages until the nineteenth century, Sinterklaas and Zwarte Piet were not even physically present during the celebrations. ${ }^{6}$ Their current representation was only established in 1850, when Jan Schenkman published a book in which he created a new narrative. ${ }^{7}$ Zwarte Piet was depicted as a "devilish figure that would frighten children", which would only change in the 1960s when societal critique caused a new role for Zwarte Piet as a silly servant with a childish accent. ${ }^{8}$ These new narratives show that the current depiction of Zwarte Piet is relatively modern and that the tradition has changed before.

Despite his image as clumsy, surveys have shown that children nowadays see Zwarte Piet as smart, hardworking, and brave. ${ }^{9}$ However, a lot of people still criticize the image of the figure. As one protestor once said: Sinterklaas rides on a horse while Black Pete walks, runs and jumps, the Saint speaks impeccable Dutch, while Zwarte Piet stumbles through the language, the Saint is noble and takes his yearly duties seriously, while Zwarte Piet is irresponsible, does all the heavy lifting when delivering toys and sliding down chimneys during the Sinterklaas season. ${ }^{10}$ Besides this role division and Zwarte Piet's clumsy character, current criticism emphasizes his black color, thick lips and controversial clothing. Many of the protestors believe that Zwarte Piet is a modern representation of the racist blackface caricature. ${ }^{11}$

\section{PROTEST AGAINST ZWARTE PIET}

Modern protest against the racist features of Zwarte Piet arose in the early 2010s, with the rise of activists such as Quinsy Gario, Jerry Afriyie, and Sandew Hira. The last once said the following to counter the argument that Zwarte Piet is black because he climbs down the chimney: How can a Dutch chimney be so different from all other chimneys that a white person can go down and come out the other end as an African? ${ }^{12}$

$5 \quad$ K. Lemmens, “The Dark Side of 'Zwarte Piet'...”, p. 121.

6 J. Rodenberg, P. Wagenaar, “Essentializing 'Black Pete': Competing Narratives Surrounding the Sinterklaas Tradition in the Netherlands", International Journal of Heritage Studies, vol. 22, no. 9 (2016), p. 720 .

K. Lemmens, “The Dark Side of 'Zwarte Piet'...”, p. 123.

8 Ibid., p. 124.

9 Ibid.

10 A.D. Reyes, "Performativity and Representation in Transnational Blackface: Mammy (USA), Zwarte Piet (Netherlands), and Haji Firuz (Iran)", Atlantic Studies, vol. 16, no. 4 (2018), p. 532.

11 E. Koning, "Zwarte Piet, een blackfacepersonage”, Tijdschrift voor Geschiedenis, vol. 133, no. 4 (2018), p. 561.

12 E. Raboteau, “Who is Zwarte Piet?", Virginia Quarterly Review, vol. 90, no. 1 (2014), p. 144. 
The activists started a campaign with the slogan "Zwarte Piet is racist", which triggered defensive reactions from proponents of Zwarte Piet. Over time the discussion became increasingly heated on both sides, and in 2013 the United Nations even sent a letter to the Dutch authorities to ask for more information about the cultural tradition. The perceived intervention of the UN boosted polarization in Dutch society even further, as some argued that foreign officials should not intervene in a national tradition. A petition (Dutch:petitie) called Pietitie to defend the traditional character of Zwarte Piet became a major success, and ever since the discussion has escalated. Proponents of Zwarte Piet argue that the depiction of the figure is not racist at all, as the intentions behind the festival are good. ${ }^{13}$ It has often been argued that children don't see any harm in the image of Zwarte Piet ${ }^{14}$, while critics have no right to change elements of a Dutch tradition. ${ }^{15}$

The protests against Zwarte Piet have had mixed results since 2010. On one hand, surveys have shown a minor shift towards acceptance for modernization of the appearance of Zwarte Piet. In 2013, 89\% of Dutch citizens were in favor of the traditional image of Zwarte Piet, while in 2017 this number had decreased to $68 \% .{ }^{16}$ However, the reaction to the demonstrators has become more aggressive and even violent in recent years.

A key event took place in 2017, when an entire highway was blocked by a group of Zwarte Piet proponents. This group attempted to prevent anti-Zwarte Piet demonstrators from arriving at the location of their protest. The group argued that they could not allow the demonstrators to protest in a place where children would be present, but video footage shows the hostile and aggressive character of their action. The same occured during later clashes. In 2018, videos of a protest in Eindhoven dominated Dutch media for a while. These videos show large crowds throwing eggs at the demonstrators, and some individuals even greet them with Nazi salutes. The popular media outlet VICE shared a video which shows groups of grown men chanting she'sjust a whore of the blacks and other similar obscenities, often while being accompanied by their children. ${ }^{17}$

Such events show the radicalization in this particular debate. In 2010 it started off with a simple disagreement and some public discussions, but nine years later the country has seen blocked highways, aggressive behavior, offensive chants and a clear revival of nationalism.

One might expect to see a strong reaction from politicians and other officials, to ensure the constitutional right to protest. The opposite is the case: the police have often tolerated this offensive behavior and on the contrary tried to prevent the demonstrators

13 K. Lemmens, “The Dark Side of 'Zwarte Piet'...”, p. 127.

14 Ibid., p. 124.

15 O. Tempelman, “Tradities in één keer aanpassen? Kleine kans", De Volkskrant, 30 November 2018, at <https://www.volkskrant.nl/nieuws-achtergrond/tradities-in-een-keer-aanpassen-kleine-kans $\sim$ be $88 \mathrm{fb} 1 \mathrm{f} />$.

16 G. Rademaker, "Draagvlak voor traditionele Zwarte Piet loopt terug”, EenVandaag, 22 November 2017, at <https://eenvandaag.avrotros.nl/panels/opiniepanel/alle-uitslagen/item/draagvlak-voortraditionele-zwarte-piet-loopt-terug/>.

17 Ch. Pugmire, "Siegheilen voor Zwarte Piet", VICE Nederland, 18 November 2018, at <https://www. vice.com/nl/article/j5zpq4/siegheilen-voor-zwarte-piet $>$. 
from arriving at the destination of their protest. ${ }^{18}$ Prime Minister Mark Rutte has repeatedly said that this discussion is not a political matter, and that in his opinion Zwarte Piet is a beautiful aspect of a tradition for children. ${ }^{19}$ Opposition parties have expressed their disapproval of these statements, but it is clear that government officials are not making an effort to ensure the demonstrators' right to protest .

In short, the developments in recent years have shown an increased polarization of Dutch society and a clear revival of nationalism. Zwarte Piet is seen as an aspect of traditional Dutch culture and every form of criticism is seen as non-Dutch. This applies to the criticism of the Dutch demonstrators, but also to the criticism of external parties such as the United Nations. Populist and anti-globalization parties have used these events to condemn the influence of the international community on Dutch internal affairs, and in that sense the revival of nationalism in The Netherlands could prove to be a challenge for European identity. Instead of showing willingness to discuss and understand the other, the debate has transformed into a matter of "us versus them".

\section{CONCLUSION}

The tradition of Sinterklaas and Zwarte Piet has been an innocent festival for many in The Netherlands. For others - however - it has been a painful memory of Dutch colonialism and social inequality. The protests have become louder and louder in recent years, which has caused a counter-reaction from people who did not see any harm in the national tradition. The discussion escalated and there has been a remarkable rise of polarization and aggression when it comes to these groups. Instead of mediating and trying to reach consensus, even politicians are using the matter for the sake of their own political agenda. Therefore, it remains to be seen if the tradition will ever be free of controversy.

Proponents of Zwarte Piet appear to emphasize its traditional aspects, even though it has been shown that the image of Zwarte Piet has changed several times in the past. It is important to note that the current unwillingness to introduce changes has developed in a time where right-wing populism has been on the rise in The Netherlands. Ever since the rise of parties such as PVV and FvD, populist views have become more important in Dutch politics. The reluctance to make adjustments to Zwarte Piet can thus be seen as a result of wider political developments, in an attempt to preserve Dutch traditions and values.

Populism has been on the rise in many European countries, which is reflected in election results all over the continent. This specific case study does not stand on its own, and it shows that traditions can function as a catalyst for nationalism if they are used to emphasize national values. While the European Union has made many attempts

18 K. van Laarhoven, “In Dokkum had politie alleen oog voor Zwarte Piet-tegenstanders", NRC, 29 April 2018, at <https://www.nrc.nl/nieuws/2018/04/29/de-hooligans-konden-gewoon-doorlopena1601268>.

19 G. Bies, "Premier Rutte: laat intocht Sinterklaas een kinderfeest blijven", Leeuwarder Courant, 19 November 2017, at <https://www.lc.nl/friesland/Premier-Rutte-laat-intocht-Sinterklaas-een-kinderfeest-blijven-22674483.html?harvest_referrer=https\%3A\%2F\%2Fwww.google.nl\%2F >. 
to generate more solidarity among Member States and emphasize a particular European identity, this case study makes clear that it could be threatened by the existence of traditions on the national level.

\section{BIBLIOGRAPHY}

Bies G., "Premier Rutte: laat intocht Sinterklaas een kinderfeest blijven", Leeuwarder Courant, 19 November 2017, at <https://www.lc.nl/friesland/Premier-Rutte-laat-intocht-Sinterklaas-een-kinderfeest-blijven-22674483.html?harvest_referrer=https\%3A\%2F\%2Fwww. google.nl\%2F>, 12 May 2019.

Hilhorst S., Hermes J., “We Have Given up so Much': Passion and Denial in the Dutch Zwarte Piet (Black Pete) Controversy", European Journal of Cultural Studies, vol. 19, no. 3 (2016), https://doi.org/10.1177/1367549415603381.

Hobsbawm E., Ranger T., The Invention of Tradition, Cambridge 1983.

Koning E., "Zwarte Piet, een blackfacepersonage", Tijdschrift voor Geschiedenis, vol. 133, no. 4 (2018), https://doi.org/10.5117/TVGESCH2018.4.001.KONI.

Laarhoven K. van, "In Dokkum had politie alleen oog voor Zwarte Piet-tegenstanders", NRC, 29 April 2018, at <https://www.nrc.nl/nieuws/2018/04/29/de-hooligans-konden-gewoon-doorlopen-a1601268>, 12 May 2019.

Lemmens K., "The Dark Side of 'Zwarte Piet': A Misunderstood Tradition or Racism in Disguise? A Legal Analysis", The International Journal of Human Rights, vol. 21, no. 2 (2007), https://doi.org/10.1080/13642987.2016.1276448.

Pugmire Ch., "Siegheilen voor Zwarte Piet", VICE Nederland, 18 November 2018, at <https:// www.vice.com/nl/article/j5zpq4/siegheilen-voor-zwarte-piet>, 12 May 2019.

Raboteau E., "Who is Zwarte Piet?", Virginia Quarterly Review, vol. 90, no. 1 (2014).

Rademaker G., "Draagvlak voor traditionele Zwarte Piet loopt terug", EenVandaag, 22 November 2017, at <https://eenvandaag.avrotros.nl/panels/opiniepanel/alle-uitslagen/item/ draagvlak-voor-traditionele-zwarte-piet-loopt-terug/>, 15 May 2019.

Reyes A.D., "Performativity and Representation in Transnational Blackface: Mammy (USA), Zwarte Piet (Netherlands), and Haji Firuz (Iran)", Atlantic Studies, vol. 16, no. 4 (2018), https://doi.org/10.1080/14788810.2018.1490508.

Rodenberg J., Wagenaar P., "Essentializing 'Black Pete': Competing Narratives Surrounding the Sinterklaas Tradition in the Netherlands", International Journal of Heritage Studies, vol. 22, no. 9 (2016), https://doi.org/10.1080/13527258.2016.1193039.

Tempelman O., "Tradities in één keer aanpassen? Kleine kans", De Volkskrant, 30 November 2018, at <https://www.volkskrant.nl/nieuws-achtergrond/tradities-in-een-keer-aanpassen-kleine-kans $\sim$ be $88 \mathrm{fb} 1 \mathrm{f} />, 15$ May 2019.

Kevin MENAGIE - holds a BA degree in European Studies at the University of Amsterdam, while he is currently working to obtain a MSc degree in European Politics and External Relations at the same university. He has a strong interest in European culture and politics and is also affiliated to the University of Amsterdam as a student assistant. 